\title{
On the acquisition of distributivity in Yudja
}

\section{Sobre a aquisição da distributividade em Yudja}

Suzi Lima

Universidade Federal do Rio de Janeiro, Rio de Janeiro, Rio de Janeiro / Brasil University of Toronto, Toronto, Ontario / Canada suzilima1@gmail.com

Abstract This paper explores the acquisition of distributivity in Yudja (Tupi, Brazil) based on a study with children and adults. In this paper, we explore experimentally the hypothesis discussed in previous work (LIMA, 2008) that verbal reduplication is a pluractional marker (LASERSOHN, 2005) that also conveys distributivity. Two preference tasks were performed with 11 adults and 17 children. Adults' results show that the interpretation of ambiguous sentences is affected by the form of the noun phrase (conjoined nouns, pluralized nouns or bare nouns). Children's results suggest that they have an overall preference for a distributive interpretation of sentences regardless of the verb form and the NP type.

Keywords distributivity; Yudja; verbal reduplication; plural; bare nouns.

Resumo Este artigo explora a aquisição da distributividade em Yudja (Tupi, Brasil) a partir de um estudo com crianças e adultos. Nesta pesquisa, exploramos experimentalmente a hipótese discutida em trabalhos anteriores (LIMA, 2007, 2008), segundo os quais reduplicação verbal é um marcador pluracional (LASERSOHN, 1995) que também expressa distributividade. Duas tarefas de preferencialidade foram feitas com 11 adultos e 17 crianças. Os resultados dos adultos sugerem que a interpretação de sentenças ambíguas é afetada pelo tipo de sintagma nominal. Os resultados das crianças sugerem uma preferência por uma leitura distributiva independentemente das propriedades do verbo e do sintagma nominal.

Palavras-chave: distributividade; Yudja; reduplicação verbal; plural; nomes nus. 
Recebido em: 5 de janeiro de 2017.

Aprovado em: 23 de março de 2017.

\section{Introduction}

Much work in formal semantics has explored the constrast between distributivity and nondistributive interpretations (collective and cumulative). One particular puzzle that will be explored in this paper is the ambiguity of sentences such as the following:

(1) Three architects designed four buildings.

(USSERY, 1998, p. 1)

This sentence can be interpreted as distributive (covert ${ }^{1}$ distributivity as no distributive quantifier, such as each, is inserted) in which case the total number of buildings is twelve. This sentence also allows nondistributive readings such as a collective reading (where the total number of buildings is four and the three architects worked together on each of them) and a cumulative reading (where the number of buildings is four, but the arrangement of the three architects working per building can vary). A debate in formal semantics is how these interpretations are derived. Authors such as Kratzer (2001) argue in favor of lexical cumulativity where collective and cumulative interpretations are derived via the same structure, and are the default interpretations. Under this view, distributivity is derived via a different operation (phrasal cumulativity): a * operator that pluralizes the VP. One prediction of this analysis is that distributivity would be more costly than nondistributive interpretations. The marginality of the distributive interpretation for sentences as (1) has been a central aspect for debate in the literature (CHAMPOLLION, to appear) and experimental evidence is inconclusive in showing whether covert distributivity is marginal for sentences such as (1) (Dotlačil, 2010 apud Champollion to appear). Authors such as Dotlačil (2010) argue that the marginality could be a result of a pragmatic principle: if the intention

\footnotetext{
${ }^{1}$ Following Champollion (to appear) we are using in this paper the terms covert distributivity and overt distributivity.
} 
is to convey distributivity, speakers would prefer to use a distributive operator such as each. Below we review some studies that explore covert and overt distributivity experimentally.

Pagliarini et al. (2012) performed truth value judgment tasks with Italian adults and children (189 children -4 to 13 years of age; 97 adults). In their study, for sentences like "The boys are building a tower", adults accepted the sentence to be associated with a distributive-like picture $50 \%$ of the time. For children, an age effect was found: younger children (9 years or younger) accepted the sentence without an overt distributive quantifier as describing the distributive scene $90 \%$ of the time. Older children showed an adult-like behavior (73\% acceptance for 13-yearolds). The authors argue that the rejection of the distributive interpretation of sentences with plural DPs is correlated with the acquisition of each.

Syrett and Mussolino (2013) have also shown, based on a truth value judgment task, that adults accept sentences with plural DPs (without each) to describe a distributive scene in $79 \%$ of the trials (3-year-olds did so in $91.7 \%$ of the trials and 4 -year-olds in $98.3 \%$ of the trials). Note, however, that in a preference task where participants had to choose between a collective and a distributive picture (SYRETT; MUSSOLINO, 2013, Experiment 2), adults preferred a collective interpretation over a distributive one for sentences with plural DPs (without each) in most of the trials $(88.9 \%)$. Children showed the opposite pattern (preference for collective in $31.5 \%$ of the trials). Other authors have presented similar results. Ussery (1998) has also shown a preference for non-distributive readings over distributive readings regardless the type of DP (conjoined, plural DPs) for English speaking adults. Similarly, Brooks and Braine (1996) have explored the interpretation of sentences including numerals (Three (actors) are (verb)ing an (object)) in a task where participants heard a sentence and were asked to choose the picture that was a better match (distributive or collective). Twenty adults and 100 children (4 to 9 years of age) participated in the study. The adults overwhelmingly preferred to associate a collective interpretation to sentences such as "Three children built a raft" both in the active and passive voice $(97.5 \%$ and $100 \%$, respectively). The study has also showed that the number of collective pictures selected for this kind of sentence increases with age: 4 -year-olds selected the collective picture in $62.2 \%$ of the time for active voice sentences and $53.3 \%$ of the time for passive voice sentences (cf. BROOKS; BRAINE, 1996, p. 250). 
Online reading time studies such as Frazier et al. (1999, p. 1771) have shown that distributive sentences take longer to be processed than collective sentences. According to the authors,

$[\ldots]$ collective interpretations may be preferred only because they avoid the need to postulate multiple events (which is claimed to be cognitively costly by Harris, Clifton, \& Frazier, submitted; Majewski, in preparation, a claim termed the 'no extra times' or NET hypothesis). Alternatively, the simplicity of the Logical Form (LF) representation of a conjoined NP, which lacks a distribution (D) operator (Heim, Lasnik, \& May, 1991), might give rise to the initial collective preference. Both hypotheses are plausible and are not mutually exclusive.

The variability of experimental results in the literature suggests that there is some cross-linguistic variation in the acceptability of covert distributivity (cf. CHAMPOLLION, to appear; 10, GIL, 1982). Despite that, most adult studies indicate that nondistributive interpretations are preferred over distributive interpretations for sentences without an overt distributive marker. Acquisition studies present a different pattern, as distributive interpretations are not necessarily dispreferred for children (cf. PAGLIARINI et al., 2012; SYRETT; MUSSOLINO, 2013).

Given this debate, the goal of this paper is twofold: first, we would like to evaluate the availability of the covert distributive interpretation in Yudja; second, we want to explore the interpretation of sentences that are overtly marked for distributivity via verbal reduplication. We discuss in this paper whether the type of NP (bare singular, bare plural or conjoined NP) affects the interpretation of sentences in the case where the verb is reduplicated and in the case where it is not.

The paper is organized as follows: Section 2 presents an overview of the nominal properties of Yudja. Section 3 presents an overview of verb phrases in Yudja with a particular emphasis on the formation of verb reduplication and its meaning. Section 4 presents a formal analysis of pluractionality in Yudja. Section 5 presents an offline preference study that investigates covert and overt distributivity in the language. 


\section{Characteristics of Noun Phrases Yudja}

Bare arguments Yudja is a number-neutral language, i.e. nouns are unspecified for number (singular, plural). Furthermore, nouns are bare and unspecified for definiteness (definite or indefinite):

(2)

$\begin{array}{lll}\text { ali } & b a \dddot{i} & \text { ixu } \\ \text { child } & \text { paca } & \text { eat }\end{array}$

'(A/the) child(ren) eat(s)/ate (a/the) paca(s)'

Literal: 'an unspecified number of children eat an unspecified number of pacas in an unspecified number of events'.

Plural Yudja has an optional plural morpheme $-i$ restricted to [+ human] nouns (FARGETTI, 2001):

(3a) Senahï kota ixu man snake eat

'(A/The) man/men ate/eat(s) (a/the) snake(s)'

Literal: 'an unspecified number of men eat/ate an unspecified number of snakes in an unspecified number of events'.

(3b) Senahï-i kota ixu

man-PL snake eat

'(The) men ate/eat (a/the) snake(s)'

Literal: 'more than one man eat/ate an unspecified number of snakes in an unspecified number of events'.

(3c) kota senahï-i ixu

snake man-PL eat

'(A/the) snake ate/eat(s) (the) men'

Literal: 'an unspecified number of snakes eat/ate more than one man in an unspecified number of events'.

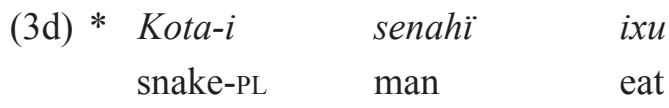


$(3 e) *$ Senahï

$\begin{array}{ll}\text { kota-i } & i x u \\ \operatorname{man} & \text { snake-PL }\end{array}$

eat

The example ( $3 a)$ means that either a single man or more than one man ate snake(s). The examples (3d) and (3e) are ungrammatical because the morpheme $-i$ cannot be associated with [- human] nouns. ${ }^{2}$

\section{Characteristics of verb phrases in Yudja}

Verbs in Yudja are by default unspecified for number of events. The examples are presented below:
(04) João
anï
ba $\dddot{\imath}$
apï
João that
paca
shoot
'João shot/shoots at that paca'
Literal: 'João shot/shoots one single paca in an unspecified number of events'
(05) João itxïbï Maria-be kamema
João many Maria-DAT necklace
'Pedro gave/gives many necklaces to Maria'
Literal: 'Pedro gave/gives many necklaces to Maria in an unspecified number of events'

\footnotetext{
${ }^{2}$ Optional and restricted plural morphology for nouns is not peculiar to Yudja. Some of other Tupi languages present restrictions on the distribution of plural morphology. In Gavião (MOORE, 1984), the morpheme éèy is restricted to [+animate] nouns. In Xipaya (RODRIGUES, 1995, p. 10)) the morpheme $-i$ is restricted to subjects (inanimate or animate). In Kamaiurá the morphemes -met/-het/-wet/-n are associated with [+animate]/ [+human] (SEKY, 2000, p. 59). In Karitiana (family Arikém) and Karo (family Ramarama) there is no plural morpheme for nouns (MÜLLER; STORTO; COUTINHO, 2005; GABAS Jr., 1999, p. 41, respectively). Mekéns (family Tupari) is the only language in which an unrestricted plural morpheme is attested. The plural morpheme -iat is unrestricted and can be optional if other plural morphemes are overt in a sentence (GALUCIO, 2001, p. 29).
} 


$\begin{array}{ccc}\text { (06) Senahi } & \text { kota } & i x u \\ \text { man } & \text { snake } & \text { eat }\end{array}$

'(A/the) man/men ate/eat (a/the) snake(s)'

Literal: 'an unspecified number of men ate/eat(s) an unspecified number of snake(s) in an unspecified number of events'

In (04), (05), and (06), the number of events is strongly context dependent. In (04) and (05), a clear number of subjects (in both cases, singular subjects defined by the proper names) and a clear number of objects (in (04) a singular paca, in (05) a plural number of necklaces and a single beneficiary (Maria)) are involved. In these cases the only argument that is not specified for number is the event ( $i x u$ ' eat' and upiku 'give', respectively). Therefore, a single or many different events can be denoted by the verb, according to the context. The variety of possible readings is manifested when we have bare nouns. In (06) the two bare nouns (senahï, 'man' and kota, 'snake') are unspecified for the number of entities, i.e., they can refer to singular or plural entities. Because the verb is also unspecified for number and type of events denoted, (06) can be interpreted in a wide range of scenarios: (i) singular: one man ate one paca; (ii) unmarked: men ate pacas in various possible combinations; (iii) collective: a group of men ate (a) paca(s); (iv) distributive: for each man there was an event of eating (a) paca(s).

In sum, a non-reduplicated verb can have a large number of possible readings, including collective and cumulative readings. These different readings are possible because nouns in Yudja, as presented before, are number-neutral, i.e., they can denote singularities or pluralities. For that reason, the involvement of one participant or many participants in one or more than one event are possible when the noun is bare and the verb is not modified for number of events.

\subsection{On the basics of reduplication: morphology}

Fargetti (2001, p. 178) first described verbal reduplication in Yudja. ${ }^{3}$ The author argues that reduplication expresses both plurality of

\footnotetext{
${ }^{3}$ Fargetti (2001) presents a phonological analysis for verbal reduplication in Yudja that I will not reproduce here because this paper focuses on the semantic aspects of verbal
} 
arguments (subjects or objects) and reiteration (when an event is realized more than once). Fargetti argues that Yudja has two types of reduplication processes: (i) infixation (which is equivalent to partial reduplication) (djidaku 'hit'> djidaidaku) that expresses plurality of subjects/objects, and (ii) suffixation (which is equivalent to total reduplication) (atxu 'bite' $>$ atxutxu) that expresses reiteration.

Another morphological aspect of verbal reduplication described in Lima (2008) is that inflectional morphemes do not reduplicate. This explains why in the case of the transitive verb atxu 'bite' the morpheme $a-$, which forms transitive verbs in the language, does not reduplicate. The same can be observed in a series of cases with other inflectional morphemes such as realis $-u$ and verbalizers $-k-,-h-$. See the examples below: ${ }^{4}$
(07a) Count:
a-bï
a-bï bï
T- verb root
T-root $\sim$ RED
(07b) hug:
a-biii
a-bïi bïi
T-verb root
T-root $\sim$ RED
(07c) shoot
a-pï
a-pï p $\ddot{i}$
T-root
T-root $\sim$ RED
(07d) extinguish
a-mi-h-u
a-mi $\sim$ mi-h-u
T-root-VBLZ-REALIS
T-root $\sim$ RED-REALIS
(07e) hurt
du-k-u
$\mathrm{du} \sim \mathrm{du}-\mathrm{k}-\mathrm{u}$
root- VBLZ-REALIS
root $\sim$ RED-VBLZ-REALIS
(07f) fall
bïdï-t-u
bidï $\sim$ dï-t-u
root-VBLZ-REALIS
root $\sim$ RED-VBLZ-REALIS

\footnotetext{
reduplication. Please consult Fargetti (2001) for a detailed analysis on the phonological properties of verbal reduplication in the language.

${ }^{4}$ There are exceptions for this rule such as the mood morpheme that appears reduplicated for some verbs. This aspect needs further investigation.
} 
$\begin{array}{lll}\text { (07g) peel } & \text { a-sa-k-u } & \text { a-sa } \sim \text { sa-k-u } \\ & \text { T-root-VBLZ-REALIS } & \text { T-root-RED-VBLZ-REALIS }\end{array}$

(LIMA, 2008)

In the examples below, Fargetti (2001) argues that partial reduplication pluralizes the subject (08b) or the object (09b) (Fargetti 2001, 178):

Partial reduplication
(08a) Una e-duku
(08b) Ulu'udi
$e-d u \sim d u k u$
1s REFL-hurt
$1 \mathrm{PL}$
REFL-RED hurt
'I hurt myself'
'We hurt ourselves'
(FARGETTI, 2001, p. 177)
(FARGETTI, 2001, p. 177)

Partial reduplication
(09a) Una e-djidaku e-be (09b) Una ese-dji dai daku ese-be $1 \mathrm{~s} 2 \mathrm{~s}$-hit 2s-DAT $1 \mathrm{~s}$ 2PL-hit-RED 2PL-DAT
'I hit you'
'I hit you (plural)'

(FARGETTI, 2001, p. 211) (FARGETTI, 2001, p. 213)

However, there are examples where partial reduplication occurs and plurality of subjects or objects cannot obtain as both refer to singular entities:
(10a) Una e-djidaku
(10b) Una e-dji $\sim d a i \sim d a k u$
1s 2s-hit 1s 2s-hit-RED
'I hit you' (in an unespecified 'I hit you (in different events)' number of events) 


$\begin{array}{llll}\text { (10c) João Maria yaekua (10d) } & \text { João Maria yaekua kua } \\ \text { João Maria remember } & \text { João Maria remember-RED } \\ \text { 'João remembers/remembered Maria } & \text { 'João always remembers/ } \\ \text { (unspecified number of events)' } & \text { remembered Maria' }\end{array}$

Based on these facts, we argued in previous work that reduplication (partial or full reduplication) in Yudja expresses plurality of events (cf. LIMA, 2007). According to this analysis, plurality of arguments is not a result of verbal reduplication, but is due to the fact that nouns are numberneutral in Yudja. Hence, reduplication is a mechanism to pluralize the argument event and it must be dissociated from the pluralization of other arguments (subject/object).

It is not just morphological reduplication that expresses multiplicity of events or subevents. In Yudja there are verbs that are lexically reduplicated, i.e. non-reduplicated forms of these verbs are not attested. Most of the lexically reduplicated verbs describe events that have an internal repetition of events. This would explain why these verbs are lexically reduplicated. Some examples are presented below:

$\begin{array}{llll}\text { (11) Spoil } & \text { Lãmïmï } & \text { Fry } & \text { lusïrïrï } \\ \text { Sneeze } & \text { Axi’axi } & \text { Steal } & \text { pa'ia'ia } \\ \text { Scratch } & \text { Atxatxaku, ata'ata } & \text { blink } & \text { ipumipumi } \\ \text { Cry } & \text { yayaya } & \text { write } & \text { waxĩwaxĩ } \\ \text { Tremble } & \text { Ari'ari } & \text { explode } & \text { pararaka } \\ \text { Cough } & \text { Ese'ese } & \text { blend } & \text { yukukutu } \\ \text { Vomit } & \text { Ena'ena } & \text { scream } & \text { azahaha } \\ \text { Boil } & \text { kura'kura } & \text { crawl } & \text { txitxiku }\end{array}$

\subsection{Interpretations of reduplication: semantics}

In Yudja, reduplication is a way to express multiplicity of events. ${ }^{5}$ We will see that the distribution may be over time and/or space

\footnotetext{
${ }^{5}$ In Tupi languages, verbal reduplication is a common process that is usually associated with pluractionality of events. In Mekéns (Tupari family) (GALUCIO, 2001, p. 104), any verb can be reduplicated to express iterativity or repetition of an event. In Munduruku
} 
or over participants. Recall examples (04) and (06) repeated below as (12a) and (13a), respectively. Unlike (12a) and (13a), their reduplicated counterparts in (12b) and (13b) cannot denote singular events:

\begin{tabular}{|c|c|c|c|c|}
\hline \multirow[t]{3}{*}{$(12 \mathrm{a})$} & $\begin{array}{l}\text { João } \\
\text { João }\end{array}$ & $\begin{array}{l}\text { anï } \\
\text { that }\end{array}$ & $\begin{array}{l}b a^{\prime} \dddot{~} \\
\text { paca }\end{array}$ & $\begin{array}{l}\text { apï } \\
\text { shoot }\end{array}$ \\
\hline & \multicolumn{4}{|c|}{ 'João shot/shoots at that paca' } \\
\hline & \multicolumn{4}{|c|}{$\begin{array}{l}\text { Literal: 'João shot/shoots one single paca in an unspecifi } \\
\text { number of events' }\end{array}$} \\
\hline \multirow[t]{2}{*}{$(12 b)$} & João & anï & $b a^{\prime} \dddot{\imath}$ & $a p \ddot{i} \sim p \ddot{i}$ \\
\hline & João & that & paca & shoot.RED \\
\hline
\end{tabular}

$\begin{array}{lll}\text { (13a) Senahï } & \text { kota } & \text { ixu } \\ \text { man } & \text { snake } & \text { eat }\end{array}$

'(A/the) man/men ate/eat (a/the) snake(s)'

Literal: 'an unspecified number of men ate/eat(s) an unspecified number of snake(s) in an unspecified number of events'

(family Munduruku) reduplication expresses the extension of the event described by the verb or its repetition (PICANÇO, 2005, p. 376; ANGOTTI, 1998, p. 15; GOMES, 2007). For Gomes (2007), reduplication may also express an extension of the duration of the event or participant pluralization. In Gavião (family Mondé) reduplication expresses repetition of an event (MOORE, 1984, p. 241). In Xipaya (family Juruna), reduplication expresses the extension of the duration of the event (RODRIGUES, 1995, p. 68). In Karitiana (family Arikém), reduplication expresses pluractionality of events (MÜLLER, SANCHEZ-MENDES, 2008). In Karo (family Ramarama) reduplication is associated with ideophones (not to verbs) and express iterativity or continuous aspect. Finally, in Kamaiurá (family Tupi Guarani) reduplication is associated with iterativity, successiveness and intensity (SEKI, 2000, p. 133-141). 
$(13 b)$

$\begin{array}{lll}\text { Senahi } & \text { kota } & i x i \sim i x i \\ \text { man } & \text { snake } & \text { eat } \sim \text { RED }\end{array}$

'(A/the) man/men ate/eat (a/the) snake(s) many times'

\# '(A/the) man/men ate/eat (a/the) snake(s) in a single event'

According to Cusic (1981) many possible interpretations can be associated with reduplication cross-linguistically. In Yudja, one possible interpretation associated with reduplicated verbs is distributivity, as presented below (14b):

(14a) Wi'ubia etu

Tracajá egg fall

'(A/the) egg(s) fell/falls down'

Literal: 'an unspecified number of eggs fell/falls down in an unspecified number of events'

(14b) Wïubia etu tu

Tracajá egg fall-RED

'(A/the) egg(s) fell/falls down (each one at a time)'

Another reading that is commonly associated with reduplication of verbs is habituality (which is a type of distributivity):

(15a) Una yaekua tese

$1 \mathrm{~s}$ remember $3 \mathrm{PL}$

'I remembered/remember them'

Literal: 'I remembered/remember them in an unspecified number of events'

(15b) João Maria yaekua kua

João Maria remember-RED

'João always remembers/remembered Maria (multiple events)' 
Finally, reduplicated verbs can be associated with iterative readings:

Akayawi $\quad$ i-djidaku
door $\quad 3$-hit
'(They) hit (a/the) door'

Literal: 'someone hit an unspecified number of doors in an unspecified number of events'

(16b)

Akayawi $\quad$ i-dji dai daku
door $\quad 3$-hit $\sim$ RED
'(They) hit (a/the) door(s) many times, continuously',

We saw that verbs can be fully or partially reduplicated in Yudja and in all cases, verbal reduplication expresses multiplicity of events. One prominent type of multiplicity of events is distributivity (in time or by participant). How multiplicity of events is interpreted ultimately depends on the context and on the Aktionsart of the verb (cf. Lima, 2007). We argue that more than one possible interpretation of the reduplicated verb is possible (either temporal distribution of participant-based distribution for instance) but in all cases the verb denotes multiple events.

\subsection{Suppletion}

In Yudja, suppletion is also related to plurality of events and/ or arguments and the alternation between intransitive and transitive predication, similar to Xipaya (RODRIGUES, 1995), which also belongs to the Juruna family. ${ }^{6}$ Below, I present the verbs that have a suppletive

\footnotetext{
${ }^{6}$ Like reduplication, suppletion expressing plurality is common in Tupi languages. In Mekéns (family Tupari), different verb roots denote singular/plural arguments (GALUCIO, 2001, p. 54-55). In Munduruku (family Munduruku), Dioney Moraes (p.c.) argue that there is no verbal suppletion, but only suppletion of ideophones. In Gavião (family Mondé) verbal suppletion expresses plurality of arguments or plurality of events (MOORE, 1984, p. 165, 239). In Xipaya (family Juruna), verbal suppletion has two main functions: marking valence alternation and plurality of events (RODRIGUES, 1995). The same holds of Karitiana (LUCIANA STORTO, p.c.). Finally, in Karo (family Ramarama) suppletion only occurs with intransitive roots and expresses singularity/ plurality of the arguments (GABAS Jr. 1999, 46).
} 
form. Most of the suppletive verbs in Yudja express plurality, except 'toast' ( $u$ 'I, intransitive and hunu, transitive):

(17)

Walk/Run

Fall

Cry (for a death)

Fly

Paint

Get/Buy

Give

Drop

Get pregnant

Wash

Kill
Neutral verb form Plural

Tahu

Ala

E'a

Ãũ

Itxiaku

Ita

(i)kua

Daïku

Imambïu

(i)tutu

Abaku
Wãnã

Etu

Yayaya

Ebataku

ãpiapinu

ĩwã

upiku

daraku

Lapiku

aututu

Adïkãũ

(LIMA, 2008)

As an example, consider the verb 'give' which can have a neutral form as in (18a) or a plural form as in (18b):
(18a) Una iidja
be
aparu
kua
$1 \mathrm{~s} \quad$ woman
DAT
beiju
give
"I gave/give beiju to (a/the) woman/women"
Literal: 'I gave/give an unspecified number of beijus to an unspecified number of women in an unspecified number of events'.

(18b)
Una iidja be
aparu
upiku
$1 \mathrm{~s} \quad$ woman DAT
beiju
give-PL
'I gave/give beiju(s) to each woman' 


\section{Theoretical analysis: reduplication and pluralization of nouns}

This analysis is based on the idea that action sentences and stagelevel predicates have an event argument (DAVIDSON, 1967, KRATZER, 1989). To illustrate this proposal, consider (19):

(19) The choir sang the Guillaume.

(20a) $\exists$ e [SING (e, The choir, the Marseillaise)]

(20b) $\lambda y . \lambda x . \lambda e$ SING (e, x, y)

(DAVIDSON, 1967 apud ROTHSTEIN, 2001)

According to Davidson (1967), the verb 'sing' would have three arguments: the subject (y), the object (x) and the event, the action of singing itself(e). Kratzer (1996) proposed that external arguments are not true arguments of the verb but are introduced by an additional functional head. In this view the denotation of 'sing' is as in (20c):

(20c) $\lambda x . \lambda e \operatorname{SING}(\mathrm{x})(\mathrm{e})$

Another notion that will be assumed in this paper is cumulativity. Krifka (1992) argued (see also KRATZER, 2001) that simple predicates in natural languages are typically unmarked. A predicate $\mathrm{P}$ is unmarked if and only if it satisfies the following formula:

(21) $\forall \mathrm{x} \forall \mathrm{y}:[\mathrm{P}(\mathrm{x}) \& \mathrm{P}(\mathrm{y})] \rightarrow \mathrm{P}(\mathrm{x} \oplus \mathrm{y})$

For all $x$ and for all $y$, if $x$ is $P$ and $y$ is $P$, then the sum of $x$ and $y$ is $P$

An application of the cumulativity principle can be exemplified below, for nouns:

(22a) Cumulativity (properties of individuals) (KRATZER, 2001, p. 3 - Chapter 4, 3):

$\left.\lambda \mathrm{P}_{<\mathrm{et}>} \forall \mathrm{x} \forall \mathrm{y}[[\mathrm{P}(\mathrm{x}) \& \mathrm{P}(\mathrm{y})] \rightarrow \mathrm{P}(\mathrm{x}+\mathrm{y})]\right]$

"A function that takes a property $P$ of individuals and return the truth value True iffor all $x$ and for all $y$, if $x$ is $P$ and $y$ is $P$, then the sum of $x$ and $y$ is $P$ " 
(22b) $[$ [child $]]=\{$ Pedro, Carlos, Maria, João, Pedro+Carlos, Pedro+Maria, Pedro+João, Carlos+Maria, Carlos+João, Maria+João, Pedro+Carlos+Maria+João\}

(based on MÜLLER; SANCHEZ-MENDES, 2008)

If we observe the extension of 'child' in (22b), we can see that for every two individual child (say Pedro and Maria), their sum (say Pedro+Maria) is also in the denotation of the extension of the predicate. The predicate 'child' is therefore unmarked. Cumulativity is also defined for verbs:

(23a) Cumulativity (properties of events)

(KRATZER, 2001, 3 - Chapter 4, 3):

$\left.\lambda \mathrm{P}_{<\mathrm{st}>} \forall \mathrm{e} \forall \mathrm{e}^{\prime}\left[\left[\mathrm{P}(\mathrm{e}) \& \mathrm{P}\left(\mathrm{e}^{\prime}\right)\right] \rightarrow \mathrm{P}\left(\mathrm{e}+\mathrm{e}^{\prime}\right)\right]\right]$

'A function that takes a property $P$ of events and return the truth value True if for all $x$ and for all $y$, if $x$ is $P$ and $y$ is $P$, then the sum of $x$ and $y$ is $P$,

$$
[[\text { rain }]]=\left\{<\text { raining }_{1}>,\left\{<\text { raining }_{2}>, \ldots,<\text { raining }_{1}+\text { raining }_{2}>, \ldots\right\}\right.
$$

(based on MÜLLER; SANCHEZ-MENDES, 2008)

If we observe the extension of 'rain' in (23b), we can see that for every two raining events (say raining ${ }_{1}$ and raining ${ }_{2}$ ), their sum (say raining ${ }_{1}+$ raining $_{2}$ ) is also in the denotation of the extension of the predicate. The predicate 'rain' is therefore unmarked.

As we have seen, there is no evidence that bare nouns are singular in Yudja. Rather, we have found evidence that they are unmarked, i.e. that their denotation includes both atomic individuals and sums of individuals. Consider the examples below:

$\begin{array}{lll}\text { João } & b a \dddot{i} & a b a k u \\ \text { João } & \text { paca } & \text { kill }\end{array}$

'João kills/killed (a/the) paca(s)'

Literal: 'João kills/killed an unspecified number of pacas in an unspecified number events' 
$\begin{array}{lll}\text { Ena } & b a \dddot{i} & i x u \\ 2 \mathrm{~s} & \text { paca } & \text { eat }\end{array}$

'You eat/ate (a/the) paca(s)'

Literal: 'you ate/eat an unspecified number of pacas in an unspecified number of events'

$\begin{array}{lll}\text { Ali } & b a \dddot{i} & \text { uatxukaha } \\ \text { child } & \text { paca } & \text { pursue }\end{array}$

'(A/the) child pursues/pursued a/the paca(s)'

Literal: 'an unspecified number of children pursued/pursues an unspecified number of pacas in an unspecified number of pacas'

In all these examples, the noun $b a$ ' $i$ ('paca') can be interpreted as singular or plural, definite or indefinite; its interpretation is contextdependent. This implies that these sentences are going to be true in many different scenarios where one or more pacas were killed (24), eaten (25), pursued (26) and so on. This shows that nouns in Yudja can denote a single individual or many individuals without any additional morphology.

The facts presented in Yudja support Krifka's (1992) and Kratzer's (2001) proposal, according to which predicates are unmarked from the start. Cumulativity is given at no cost for both nouns and verbs. In other words, in Yudja, lexical cumulativity can be considered the null hypothesis for any predicate (nominal or verbal) in the language (as Müller; Sanchez-Mendes (2008) proposed for Karitiana). But if verbs can denote plural events by default, what is the function of verbal reduplication?

So far we have argue that reduplicated verbs are associated with the distribution of the event over time, time-space, or participants: 
Distribution over time (or time-space)
(27)
Jõ̃o
an
$b a$
ap $\ddot{\imath} \sim \ddot{i}$
João
that paca shoot $\sim$ RED
'João shot/shoots at that paca many times'
\# 'João shot/shoots at the pace once'

Distribution over time
Iidja
$e t u \sim t u$
$d a$
woman
fall $\sim \mathrm{RED}$
COL
'A group of women fell/falls (each one at time)'

Participant-based distribution / Distribution over time
(29)
Senahï
kota
$i x i \sim i x i$
man
snake
eat $\sim$ RED
'(A/the) man/men ate/eat snake(s) (more than one event)'
\# '(A/the) man/men ate/eat snake(s) once'

In (27), a single individual subject (João) and a single individual object (that paca) are involved in the distribution of events. As a consequence, the only possible interpretation is distribution over time. In (28), the collective morpheme $d a$ is inserted, and indicates that more than one group of women fell. In (29), because the nouns are number-neutral, at least two interpretations are possible: distribution of the event over time (one man ate snake(s) in different events) or participant-based distribution (more than one man ate snake(s) in different events). To explain how these readings are generated (time distribution and participant-based distribution), we will analyze reduplication as a pluractional marker (LASERSOHN, 1995).

In Lasersohn's proposal, pluractional markers are morphemes that do not reflect the plurality of the verb's arguments (subject/object), 
but the plurality of the verb itself, because it is the verb that represents the occurrence of multiple events (LASERSOHN, 1995, p. 241). The basic denotation of pluractional markers is presented in (30a):

$$
\begin{aligned}
& \mathrm{V}-\mathrm{PA}(\mathrm{X}) \Leftrightarrow \forall \mathrm{e} \in \mathrm{X}[\mathrm{P}(\mathrm{e})] \text { \& card }(\mathrm{X}) \geq \mathrm{n}^{7} \\
& \text { 'X is in the denotation of } V-P A \text { iff for all event e that } \\
& \text { belongs to } X \text {, e has the property } P \text { and the cardinality of } \\
& X \text { is at least as great as } n \text { ' (LASERSOHN, 1995, p. 256) }
\end{aligned}
$$

In Lasersohn's own terms (1995, p. 240): "pluractional markers attach to the verb to indicate a multiplicity of actions, involving multiple participants, times or locations". That is, in Lasersohn's analysis, a verb modified by a pluractional marker can denote an event involving separate running spaces, non-overlapping running times, or even events distributed over multiple participants. In order to capture distributive readings, Lasersohn introduces a non-overlap condition in the meaning of the pluractional marker. Specifically, the condition states that for any two events e and e', the parameters $\mathrm{f}(\mathrm{e})$ and $\mathrm{f}\left(\mathrm{e}^{\prime}\right)$ of e and e' do not overlap:

(30b) $\quad \mathrm{V}-\mathrm{PA}(\mathrm{X}) \Leftrightarrow \forall \mathrm{e}, \mathrm{e}^{\prime} \in \mathrm{X}[\mathrm{P}(\mathrm{e}) \& \neg \mathrm{f}(\mathrm{e})$ o f(e') $] \& \operatorname{card}(\mathrm{X}) \geq \mathrm{n}$ ' $X$ is in the denotation of $V-P A$ iff for all events $e$ and $e^{\prime}$ in $X$ e has a property and $f(e)$ and $f\left(e^{\prime}\right)$ do not overlap and the cardinality of $X$ is at least as great as $n$ ' (LASERSOHN, 1995, p. 256)

Distributivity is temporal, spatio-temporal or participant-based according to the value of function $f$. If the distribution is temporal, $f$ maps events to their temporal trace. If it is spatio-temporal, then $f$ maps events to their spatio-temporal trace. Finally, if it is participant-based, $f$ is a thematic function assigned by $\mathrm{V}$, i.e. a function that maps events to a particular sort of participants, such as agents or patients.

Note that there are two possible readings of distributivity in time: the "separate" reading, which is exemplified for any example from (27) to (29) and the "continuous" reading, such as in (16b, "Someone knocked/ knocks the door many times, continuously"). In the case of "separate"

\footnotetext{
${ }^{7} \mathrm{~V}$ : verb, PA: pluractional marker, e: variable over atomic events, $\mathrm{n}$ : variable over the natural numbers.
} 
readings, there is a space in time between each event or subevent. To formalize this, Lasersohn included a 'betweenness' clause to the formula in $(30 \mathrm{~b})$ resulting in $(30 \mathrm{c})$ :

(30c) V-PA (X) $\Leftrightarrow \forall$ e, e' $\in X[P(\mathrm{e}) \& \neg \mathrm{f}(\mathrm{e})$ o f(e' ) \& $\exists \mathrm{x}$ [between $\left.\left(\mathrm{x}, \mathrm{f}(\mathrm{e}), \mathrm{f}\left(\mathrm{e}^{\prime}\right)\right) \& \neg \exists \mathrm{e}^{\prime},\left[\mathrm{P}\left(\mathrm{e}^{\prime},{ }^{\prime}\right) \& \mathrm{t}=\mathrm{f}\left(\mathrm{e}^{\prime}{ }^{\prime}\right)\right]\right] \&$ card $(\mathrm{X}) \geq \mathrm{n}$

' $X$ is in the denotation of $V$-PA iff for all events $e, e$ ' in the denotation of $X$, e has the property $P$ and $f(e)$ and $f\left(e^{\prime}\right)$ do not overlap and there is an $x$ between $f(e)$ and

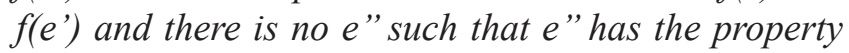
$P$ and t equals $f\left(e^{\prime \prime}\right)$ and the cardinality of $x$ is at least as great as n'

The continuous reading, on the other hand, is generated by the negation of the betweenness clause in (30c) resulting in (30d):

(30d) V-PA (X) $\Leftrightarrow \forall$ e, e' $\in \mathrm{X}[\mathrm{P}(\mathrm{e}) \& \neg \mathrm{f}(\mathrm{e})$ o f(e' ) \& $\neg \exists \mathrm{x}$ [between $\left.\left.\left(\mathrm{x}, \mathrm{f}(\mathrm{e}), \mathrm{f}\left(\mathrm{e}^{\prime}\right)\right) \& \neg \exists \mathrm{e}^{\prime}\left[\mathrm{P}\left(\mathrm{e}^{\prime}{ }^{\prime}\right) \& \mathrm{t}=\mathrm{f}\left(\mathrm{e}^{\prime}\right)^{\prime}\right)\right]\right] \&$ card (X) $\geq \mathrm{n}$

' $X$ is in the denotation of V-PA iff for all events $e, e$ ' in the denotation of $X$, $e$ has the property $P$ and $f(e)$ and $f\left(e^{\prime}\right)$ do not overlap and it is not the case that there is an $x$ between $f(e)$ and $f\left(e^{\prime}\right)$ and there is no $e^{\prime \prime}$ such that $e^{\text {" }}$ has the property $P$ and t equals $f\left(e^{\prime \prime}\right)$ and the cardinality of $x$ is at least as great as $n$,

Remember that Yudja is a number-neutral language. In this kind of language, a participant-based reading is possible if the noun in question is bare (31a) or plural (31b):
(31a) iidja
$b a \dddot{\imath}$
$i x i \sim i x i$
woman
paca
eat-RED
'(A/the) woman(women) eat(s)/ate (a/the) paca(s) in different events'



(31b)
iidja-i
$b a \dddot{\imath}$
$i x i \sim i x i$
woman-PL paca eat $\sim$ RED
'(The) women eat(s)/ate (a/the) paca(s) in different events'

The participant-based distributive reading is not possible if nouns are singularized (by demonstratives, proper names, numerals [one]). According to Lasersohn's proposal, if the noun is singularized, a temporal or temporal-spatial reading is forced, as we saw in (12b) (João anï ba' $\dddot{\imath}$ apïpi 'João shot at that paca many times'). If the noun is plural as in (31b) or bare as in (31a), the pluractional markers allow several readings including a temporal reading (which is forced if the agent argument is singular) and a participant-based reading. In all cases, multiple events are necessarily implied.

This analysis predicts that reduplicated verbs will be associated with distributive events and that they are not just indicating plurality of events given that unmarked verbs (non-reduplicated) can also be interpreted as such. It is unclear whether the plural in nouns has the same effect (distributivity). If it does, we would expect that pluralized nouns in sentences with unmarked verbs would bias distributivity. This hypothesis is tested in the study presented in the next section.

\section{Covert and overt distributivity in Yudja: a pilot study}

The analysis presented in Section 3 predicts that verbal reduplication is a way to express overt distributivity. As such, we expect that when given a sentence such as (1) "Three architects designed four buildings", if the verb is reduplicated, speakers will prefer a distributive interpretation over a nondistributive one. Conversely, if the verb is nonreduplicated, we expect that both readings will be available (distributive and nondistributive). Note, however, if the default reading is nondistributive due to lexical cumulativity, then the prediction will be that the nondistributive reading will be preferred in most trials.

One relevant question is whether the type of NP will affect the interpretation of the verb phrase. In order to test that, we manipulated three types of NPs: 1) Numeral + unmarked/bare noun (txabïu iidja 'three woman'); 2) Numeral + plural (txabïu iidjai 'three women'); 3) Conjoined Ns (João Pedro Claudio djuda 'João, Pedro and Cláudio'). In languages 
like English (USSERY, 1998), it was observed that the type of NP did not affect the results: nondistributive interpretations were preferred over distributive interpretations regardless of the NP form. ${ }^{8}$

Two different studies were performed in Yudja. Both studies were based on Ussery (1998)'s studies 1 and 2 for English.

\section{Participants}

A total of 17 children (5 3-to-5-year-olds; 2 7-year-olds; 5 8-to-9year-olds; 5 10-to-11-year-olds) and 11 adults participated in this study. ${ }^{9}$ Participants were tested individually in a room in Yudja's local central school in the Tuba Tuba village. A local teacher familiar to the children was present to facilitate all the tasks that involved children. The study was advertised in the village amongst adults and children. Parents were individually consulted on the participation of their children in the study. The children who participated in the study volunteered to do so and were formally consented by their parents who were welcome to stay in the room along with the researcher and the research assistant.

\section{Study 1: Conjoined Nouns (Preference task)}

\section{Materials and Methods}

The study consisted of a sentence in Yudja followed by a target question. After presenting the target question, the participant was exposed to two different drawings: one corresponding to a nondistributive interpretation (collective) of the sentence and one corresponding to a distributive interpretation of the sentence. Two conditions were tested:

\footnotetext{
${ }^{8}$ In previous studies with English-speaking adults and children (cf. Section 1), only pluralized DPs and conjoined DPs were manipulated as English is not a language that allows bare singulars. A similar study to the one presented in this paper in Brazilian Portuguese, a language that allows Bare Singulars, is in progress (cf. LIMA in progress). ${ }^{9}$ All children who volunteered were allowed to participate (as long as their parents authorized them). Given the wide age range in the children's test group, we were not able to perform a statistical analysis that explored the age effects within this group.
} 
Condition 1: conjoined NPs + non-reduplicated verb

(32a) João, Pedro Cláudio djuda duwadjuse apï iwãnu
João Pedro Cláudio and four dog poison
'João, Pedro and Cláudio poisoned four dogs'

'How many dogs were poisoned?'

4

(nondistributive interpretation)
12

(distributive interpretation)

Condition 2: conjoined NPs + reduplicated verb

(32b) João, Pedro Cláudio
João Pedro Cláudio
'João, Pedro and Clá
many dogs were poisoned?'

4

(nondistributive interpretation)
12

(distributive interpretation)

If verbal reduplication is associated with distributivity, we predict Condition 2 with reduplicated verbs to be associated with the distributive interpretation more than Condition 1 with nonreduplicated verbs.

The study included 7 critical items counterbalanced in two lists (each participant saw 4 items each).

\section{Study 2: Bare and Plural Noun Phrases (Preference task)}

\section{Materials and Methods}

The study consisted of a sentence in Yudja followed by a target question. After presenting the target question, the participant was exposed to two different drawings: one corresponding to a nondistributive interpretation (collective) of the sentence and one corresponding to 
a distributive interpretation of the sentence. Four conditions were manipulated in this study:

Condition 1: bare noun + non-reduplicated verb

Condition 2: bare noun + reduplicated verb

Condition 3: plural noun + non-reduplicated verb

Condition 4: plural noun + reduplicated verb

Examples for each condition are presented below:

Condition 1: Unmarked Noun + Non-reduplicated verb

(33a) Txabïu iidja tïtïri taha duwadjuse aparu ixu hree woman pregnant pred four biscuit eat 'Three pregnant women ate four biscuits'

Abï ne deda aparu ixu?

How many biscuit eat?

'How many biscuits were eaten?'

4

(nondistributive interpretation)
12

(distributive interpretation)

Condition 2: Unmarked Noun + Reduplicated verb

(33b) Txabïu iidja tïtirï taha duwadjuse aparu ixiixi Three woman pregnant PRED four biscuit eat.RED 'Three pregnant women ate four biscuits'

Abïne deda aparu ixu?

How many biscuit eat?

'How many biscuits were eaten?' 
4

(nondistributive interpretation)
12

(distributive interpretation)

Condition 3: Plural Noun + Non-reduplicated verb

(33c) Txab̈̈u iidja-i tïtïrï taha duwadjuse aparu ixu Three woman-PL pregnant PRED four biscuit eat 'Three pregnant women ate four biscuits

Abïne deda aparu ixu?

How many biscuit eat?

'How many biscuits were eaten?'

4

(nondistributive interpretation)
12

(distributive interpretation)

Condition 4: Plural Noun + Reduplicated verb

(33d) Txabüu iidja-i tïtïrï taha duwadjuse aparu ixiixi Three woman- PL pregnant PRED four biscuit eat.RED 'Three pregnant women ate four biscuits'

Abïne deda aparu ixu?

How many biscuit eat

'How many biscuits were eaten?'

4

(nondistributive interpretation)
12

(distributive interpretation)

The study included 16 critical items counterbalanced in two lists (each participant saw 8 items each). 


\section{Results}

To investigate the research questions in this study, generalized estimating equations (GEE) analyses were performed. GEE is a semi-parametric statistical technique that takes into account the interdependencies in hierarchically structured data and is appropriate for a wide variety of variable distributions (normal and skewed, continuous, dichotomous, ordinal etc.). This technique was selected to account for multiple trials for each subject within each condition of the study. Since the outcome variable in this study is binary (Colective vs distributive response), GEE analyses were performed with binomial probability distribution and logit link function.

\section{Study 1: Results ${ }^{10}$}

The percentages of Collective and Distributive responses within the two study conditions for adults and children in the sample are displayed in Table 1. As the table shows, the distribution of the two types of responses is similar across the two conditions within each age group, but the pattern is different between the age groups. Specifically, for adult subjects choose Collective more than Distributive, while children choose Distributive more than Collective.

Table 1 - Distribution of the two types of responses across conditions and age groups of the subjects

\begin{tabular}{lcccc}
\hline \multirow{2}{*}{ Study condition } & \multicolumn{2}{c}{ Adult } & \multicolumn{2}{c}{ Child } \\
\cline { 2 - 5 } & Collective & Distributive & Collective & Distributive \\
\hline Non-Reduplicated verb & $77.3 \%$ & $22.7 \%$ & $38.1 \%$ & $61.9 \%$ \\
\hline Reduplicated verb & $57.1 \%$ & $42.9 \%$ & $42.3 \%$ & $57.7 \%$ \\
\hline
\end{tabular}

The results of GEE analyses confirm the pattern observed in the sample. The difference between the two study conditions is nonsignificant,

\footnotetext{
${ }^{10}$ All children that volunteered to participate in both studies were allowed to participate (as long as their parents authorized them). Given the wide age range in the children's test group (for both studies), we were not able to perform a statistical analysis that explored the age effects inside this group.
} 
Wald $\chi^{2}(1)=.20, p=.652$. However, there is a significant difference between the two age groups, Wald $\chi^{2}(1)=5.83, p=.016$. Based on these results, we can conclude that while the majority of adult responses $(69.4 \%$ across both study conditions in the sample) are Collective - as attested in other studies presented in the literature (cf. USSERY, 1998), the majority of child responses ( $60.3 \%$ across both conditions in the sample) are Distributive. The pattern observed for children was also previously attested in the literature (BROOKS; BRAINE, 1996, PAGLIARINI et al. 2012, SYRETT; MUSSOLINO, 2013).

\section{Study 2: Results}

The percentages of Collective and Distributive responses within each of the four study conditions for groups of adults and children are displayed in Table 2. As can be seen from this table, the distribution of the two types of responses is very similar for all study conditions in the sample, with Distributive responses being more common than Collective responses. However, in the Plural + Non-Reduplicated condition the proportions of the two response types are similar for adult participants.

Table 2 - Distribution of the two types of responses across conditions and age groups of the subjects

\begin{tabular}{lcccc}
\hline \multirow{2}{*}{ Study condition } & \multicolumn{2}{c}{ Adult } & \multicolumn{2}{c}{ Child } \\
\cline { 2 - 5 } & Collective & Distributive & Collective & Distributive \\
\hline Bare + Non-reduplicated verb & $23.8 \%$ & $76.2 \%$ & $37.1 \%$ & $62.9 \%$ \\
Bare + Reduplicated verb & $17.4 \%$ & $82.6 \%$ & $36.4 \%$ & $63.6 \%$ \\
Plural + Non-reduplicated verb & $52.2 \%$ & $47.8 \%$ & $39.4 \%$ & $60.6 \%$ \\
Plural + Reduplicated verb & $33.3 \%$ & $66.7 \%$ & $37.1 \%$ & $62.9 \%$ \\
\hline
\end{tabular}

The results of GEE analyses indicate that there is no significant difference between the age groups or study conditions in the sample and cannot be generalized beyond the sample (effect of age, Wald $\chi^{2}(1)=$ $.39, p=.532$; effect of condition, Wald $\chi^{2}(3)=4.30, p=.231$ ). 


\section{Discussion}

In the first study, adults preferred a nondistributive (collective) interpretation for sentences that included conjoined nouns. Regardless of the form of the verb (reduplicated or non-reduplicated), a distributive interpretation was disfavored in most of the trials. For structures with conjoined nouns, children presented a slightly higher preference for a distributive interpretation (62\%, non-reduplicated verb; $58 \%$ reduplicated verb) over a nondistributive interpretation across verb types (reduplicated or not). The difference between the age groups was statistically significant. The results found for Yudja children were consistent with the results found in previous studies in other languages (BROOKS; BRAINE, 1996; PAGLIARINI et al., 2012; SYRETT; MUSSOLINO, 2013) where children favor a distributive interpretation over a collective interpretation in preference tasks, even for sentences without overt markers of distributivity (in the case of Yudja, in the absence of verbal reduplication).

In study 2, we did not find a statistically significant difference between non-reduplicated and reduplicated verbs across noun type (bare or plural) The distributive interpretation was preferred across all conditions, except for the condition with plural + Non-Reduplicated Verb.

Our initial prediction was that the distributive interpretation would be particularly favored only when the verb is reduplicated. Instead, in Study 2, we observed a preference for distributive interpretation even when the verb was not reduplicated and the noun was bare (Condition 1). We observed a preference for a distributive interpretation when the verb is reduplicated (compare Conditions 1 and 2 and Conditions 3 and 4), but this preference, as observed above, was not proven to be statistically significant.

Even though we did not find a statistically significant difference across the conditions, we observed that conditions 3 and 4 - those with pluralized nouns - had a smaller number of trials where the distributive interpretation was preferred. In the condition 3 (Bare noun + Nonreduplicated verb), in particular, there was no particular preference for collective or distributive interpretations. As such, the plural morpheme does not seem to trigger distributive interpretations.

For children, in all conditions, the results were numerically similar; based on the data presented on Table 2, there was a slight 
preference for the distributive over the collective interpretation. These results are parallel to other studies with children that found a general preference for a distributive interpretation (SYRETT; MUSSOLINO, 2013).

\section{Final considerations}

This paper explored a formal semantics analysis of distributivity in Yudja (Tupi, Brazil). In this paper, we investigated experimentally the hypothesis discussed in previous work (LIMA, 2008) that verbal reduplication is a pluractional marker (LASERSOHN, 1995) that is also a marker of overt distributivity in the language.

Two preference tasks were performed with 11 adults and 17 children. We manipulated verb form (reduplicated and nonreduplicated) and NP type (bare noun, pluralized noun, conjoined nouns). Sentences without reduplicated verbs were taken as examples of ambiguous sentences where distributivity is covert, as in the English sentence 'Three architects designed four buildings' which is ambiguous between a nondistributive (collective/cumulative) and a distributive interpretation. In contrast, we hypothesized that verbal reduplication could be the manifestation of distributivity in the language.

Given that, the predictions were: 1) reduplicated verbs will trigger a preference for a distributive interpretation over a nondistributive one; 2) non-reduplicated verbs will be compatible with both interpretations (distributive and nondistributive). However, if nondistributive interpretations are favored due to lexical cumulativity (for nonreduplicated verbs), then nondistributive readings would be preferred in most trials.

The results found for Yudja children were consistent with the results found in previous studies in other languages (BROOKS; BRAINE, 1996, PAGLIARINI et al., 2012; SYRETT; MUSSOLINO, 2013) where children favor a distributive interpretation over a collective interpretation in preference tasks, even for sentences without overt markers of distributivity. This was clear in Study 1 where we found a significant age effect. In Study 2, we found a numerical advantage of the distributive interpretation in all conditions, but no age effect or condition effect was found. 
For adults, we found different patterns depending on the type of NP. For conjoined nouns (Study 1), we found that participants preferred the nondistributive interpretation over the distributive interpretation. The same pattern was observed in previous studies in different languages; these results are compatible with theories that claim that a non-distributive reading is the default interpretation of this kind of predicate. For pluralized nouns and bare nouns (Study 2), we found no condition effect, but the results suggest a slight preference of the distributive interpretation when the verb is reduplicated and the noun is bare ( $83 \%$ of the trials). In all other conditions, the preference for the distributive interpretation is lower: 76\% (bare + Non-Reduplicated Verb); 67\% (Plural + Reduplicated Verb) and 48\% (Plural + Non-Reduplicated Verb).

By hypothesis bare nouns are more likely compatible with distributive and non-distributive interpretations because they are numberneutral and can be interpreted referring to single individuals as well as their sums. Studies on other languages that allow bare singulars in argument position are in progress and will be compared with the Yudja results (Lima in progress); also in progress is a more detailed analysis of the lexical semantics of the verbs and the interaction with overt and covert distributivity (LIMA, in progress).

Acknowledgments Funding for this research includes the Summer Research Stipend Program from UMass Amherst (2011) and Lewis and Clark Fund Grant (2009). Funai authorization (79/AEP/11).

\section{References}

ANGOTTI, Mary Lourdes de Oliveira. A causativização em Munduruku: aspectos morfo-sintáticos. 1998. Dissertação (Mestrado)-- University of Brasília, Brasília, 1998.

BROOKS, Patricia J.; BRAINE, M. D. What do children know about the universal quanti ers all and each? Cognition, Elsevier, v. 60, n. 3, p. 235268, 1996. https://doi.org/10.1016/0010-0277(96)00712-3

CHAMPOLLION, Lucas. Distributivity, collectivity, and cumulativity. Handbook article. Wile”s Companion to Semantics. (to appear)

CHIERCHIA, Gennaro. Mass nouns, vagueness and semantic variation. Synthese, Springer Link, v. 174, n. 1, p. 99-149, 2010. 
CUSIC, David. Verbal Plurality and Aspect. 1981. Dissertation (PhD)-Stanford University, Stanford, 1981.

DAVIDSON, Donald. Causal Relations. Journal of Philosophy, Columbia University, v. 64, n. 21, p. 691-703, 1967.

DOTLAčIl, Jakub. Anaphora and distributivity: A study of same, different, reciprocals and others. Utrecht, Netherlands: Utrecht University Dissertation, 2010.

FARGETTI, Cristina. Estudo fonológico e morfossintático da língua Juruna. 2001. Tese (Doutorado) - Unicamp, Campinas, SP, 2001.

FERREIRA, Marcelo. Event Quantification and Plurality. 1995. Dissertation (PhD) - MIT, Massachusetts, 1995.

FRAZIER, Lyn; PACHT, Jeremy; RAYNER, Keith. Taking on semantic commitments, II: collective versus distributive readings. Cognition, Elsevier, v.70, p. 87-104, 1999. https://doi.org/10.1016/S00100277(99)00002-5

GABAS Jr., Nilson. A Grammar of Karo. 1999. Dissertation (PhD)-University of California, Santa Bárbara, 1999.

GALUCIO, Ana Vilacy. The morphosyntax of Mekéns (Tupi). 2001. Dissertation (PhD) - University of Chicago, Chicago, 2001.

GIL, David. Quanti er scope, linguistic variation, and natural language semantics. Linguistics and Philosophy, Springer Link, v. 5, n. 4, p. 421472, 1982. https://doi.org/10.1007/BF00355582

GILLON, Carrie. The mass/count distinction in Innu-aimun: implications for the meaning of plurality. In: WORKSHOP ON THE STRUCTURE AND CONSTITUENCY OF THE LANGUAGES OF THE AMERICAS (WSCLA) $15^{\text {th }}$., Vancouver, 2010. Proceedings... Vancouver: UBC Department of Linguistic, 2010.

GOMES, Dioney. Reduplicacão verbal em Munduruku. In: CABRAL, Ana Suelly; RODRIGUES, Aryon (Ed.). Linguas e culturas Tupi. Brasília: LALI/UnB, 2007. p. 391-396.

KRATZER, Angelika. Stage-level and individivual level predicates. In: Papers in Quantification NSF Grant Report. Amherst: Department of Linguistics, University of Massachutts, 1989. 
KRATZER, Angelika. Severing the External Argument from its Verb. In: ROORYCK, J.; ZARING, L. (Ed.). Phrase Structure and the Lexicon. Dordrecht: Kluwer, 1996.p. 109-137.

KRATZER, Angelika. The event argument and the semantics of verbs. Amherst: University of Massachusetts, 2001. Disponível em: <http:// semanticsarchive.net/Archive/GU1NWM4Z/>.

KRIFKA, Manfred. Thematic relations as links between nominal reference and temporal constitution. In: SAG, Ivan A.; SAZBOLSCI, Anna (Ed.). Lexical Matter. Chicago: CSLI, 1992. p. 29-53.

LANDMAN, Fred. Groups, I. Linguistics and Philosophy, Springer Link, v. 12, n. 5, p. 559-605, 1989.

LASERSOHN, Peter. Plurality, Conjunction, and Events. Dordrecht, Boston: Kluwer Academic Publishers, 1995.

LIMA, Suzi. Distributivity in Brazilian Portuguese. Ms. In Progress.

LIMA, Suzi. Plurality and distributivity in Juruna: some considerations about verbal cumulativity. In: SULA, 4th., 2007, Amherst. Proceedings... Amherst: GLSA, 2007. p. 117-128.

LIMA, Suzi. A estrutura argumental dos verbos na língua Juruna (Yudja): da formação dos verbos para a análise das estruturas sintáticas. 2008. Dissertação (Mestrado) - Universidade de São Paulo, São Paulo, 2008.

LINK, Godehard. The logical analysis of plural and mass terms: A lattice theoretic approach. In: BÄUERLE, R.; SCHWARZE, C.; STECHOW, A. von (Ed.). Meaning, use and interpretation of language. Berlin: de Gruyer, 1983. p. 302-323.

MOORE, Denny. Syntax of the language Gavião Indians of Rondônia, Brazil. 1984. Dissertation (PhD) - University of New York, New York, 1984.

MÜLLER, Ana. The semantics of generic quantification in Brazilian Portuguese. PROBUS, Berlin, Mouton der Gruyter, v. 14, n. 2, 2002.

MÜller, Ana; STORTO, Luciana; COUTINHO, T. Number and the count-mass distinction in Karitiana. In: WORKSHOP ON THE STRUCTURE AND CONSTITUENCY OF THE LANGUAGES OF THE AMERICAS (WSCLA) $10^{\text {th }}$., Toronto, 2005. Proceedings... Toronto: University of Toronto, 2005. 
MÜLLER, Ana; SANCHEZ-MENDES, Luciana. Pluractionality in Karitiana. In: GRØNN, Atle (Ed.). Proceedings of SuB 12. Oslo: ILOS, 2008. p. 442-454. ISBN 978-82-92800-00-3.

PAGLIARINI, Elena; FIORIN, Gaetano; DOTLAčIL, Jakub. The acquisition of distributivity in pluralities. In: BOSTON UNIVERSITY CONFERENCE ON LANGUAGE DEVELOPMENT (BUCLD), $36^{\text {th }}$,, Boston, 2012. Proceedings... Boston: Cascadilla Press, 2012. v. 2, p. 387-399.

PARSONS, Terence. Events in the Semantics of English: A Study in Subatomic Semantics, Cambridge: The MIT Press, 1990.

PICANÇO, G. L. Munduruku: phonetics, phonology, synchrony, diachrony. 2005. Dissertation (PhD) - University of British Columbia, 2005.

RODRIGUES, Aryon. Línguas Brasileiras - Para o conhecimento das línguas indígenas. São Paulo: Loyola, 1994.

RODRIGUES, Carmen L. R. Étude morphosyntaxique de la langue Xipaya. 1995. Dissertation (PhD) - Université Paris VII, Paris, 1995.

ROTHSTEIN, Susan. Events and Grammar. Netherlands: Kluwer Academic Publishers, 2001.

SAUERLAND, Uli. A new semantics for number. In: YOUNG, R.; ZHOU, Y. (Ed.). Proceedings of SALT 13. Ithaca, NY: CLC Publications, Cornell University, 2003.

SEKI, Lucy. Gramática do Kamaiurá - Línguas Tupi-Guarani do alto do Xingu. Campinas: Editora da UNICAMP, 2000.

SYRETT, Kristen; MUSOLINO, Julien. Collectivity, distributivity, and the interpretation of plural numerical expressions in child and adult language. Language Acquisition, Bethesda, MD, v. 20, n. 4, p. 259-291, 2013. https://doi.org/10.1080/10489223.2013.828060

USSERY, Cherlon. Processing plural DPs: Collective, cumulative, and distributive interpretations. Amherst.: University of Massachusetts, 1998. 


\section{Appendix}

\section{Glossing Abbreviations}

\begin{tabular}{|c|c|}
\hline & first person \\
\hline & second person \\
\hline & third person \\
\hline COL & collective \\
\hline DAT & dative \\
\hline DECL & declarative \\
\hline HAB & habitual \\
\hline IRR & irrealis \\
\hline RED & reduplication \\
\hline REFL & reflexive \\
\hline S & singular \\
\hline PL & plural \\
\hline T & transitivizer \\
\hline & verbalizer \\
\hline
\end{tabular}

